\title{
The continuing relevance of the Milibandian perspective
}

\author{
David Coates and Leo Panitch
}

The belief in the effective transformation of the Labour Party into an instrument of socialist politics is the most crippling of illusions to which socialists in Britain have been prone ... To say that the Labour Party is the party of the working class is ... important ... but it affords no answer to the point at issue, namely that a socialist party is needed in Britain, and that the Labour Party is not it, and it will not be turned into it. To say that it is a party of the working class is, on this view, to open the discussion, not to conclude it. It might be otherwise if there was any likelihood that the Labour Party could be turned into a socialist formation; but that is precisely the premise which must, on a realistic view, be precluded. (Miliband 1976: 128, 130)

Labourism ... a theory and practice which accepted the possibility of social change within the existing framework of society; which rejected the revolutionary violence and action implicit in Chartist ideas of physical force; and which increasingly recognized the working of political democracy of the parliamentary variety as the practical means of achieving its own aims and objectives. (Saville 1973: 215; see also Saville 1988: 14)

The legacy of Ralph Miliband's writings on the Labour Party has been, and remains, both an important and a controversial one. It is also one that is much caricatured by critics unfamiliar with its central theses. Indeed, too often in collections of essays on New Labour these days, lazy throwaway lines discourage serious readers from exploring its complexity and continuing importance. So, for example, in the essays gathered to mark the Labour Party's centenary (Brivati and Heffernan 2000), the works to be discussed here were dismissed by Ben Pimlott as the 'we wuz robbed' school of party history (Jefferys 2000: 68); and even the more careful Robert Taylor reported that in the work inspired by the writings of Miliband 'trade unions were portrayed as a formidable, defensive barrier to Labour's Socialist advance, supposedly holding back the masses from commitment to a militant socialism' (Taylor 2000: 10). But neither characterisation, though perhaps appropriate to many others, is either accurate or just in respect of Miliband; and, indeed, one reason why this chapter may be of lasting value is that it will demonstrate that impropriety.

For there is a distinctively Milibandian perspective within the historiography of the Labour Party. The content and complexity of that perspective has grown over 
time, as the early work of Ralph Miliband and his sometime collaborator John Saville has been supplemented by the writings of other scholars persuaded of the importance of their initial formulations. Yet even those initial formulations were not of the 'we wuz robbed' variety. Instead, from the outset, the arguments developed by Miliband and Saville about Labour politics were far more sophisticated and important than that. From its inception, the Milibandian perspective on the Labour Party emphasised the importance of three things. It emphasised, first, the centrality of parliamentarianism to the theory and practice of Labour Party politics, and its deleterious consequences for the party's capacity to act as a successfully reformist agency when in office. It stressed, second, the functionality of the Labour Party's periodically radical rhetoric to the long-term stability of the British class structure, and its harmful consequences for the creation and consolidation of a radicalised proletariat. Third, it emphasised the inability of socialists within the Labour Party to do more than briefly (and episodically) radicalise the rhetoric and policy commitments of the party in opposition, and the deleterious consequences of that inability for the creation of a genuinely potent socialist party in Britain.

It is these three complex propositions that constitute the core of the earlyMiliband-inspired scholarship on the Labour Party and its limits; and it is with their establishment and development that this chapter is primarily concerned.

\section{The Labour Party and working-class incorporation}

The character of Miliband's early writings on the Labour Party have been documented in the previous chapter, and will not be re-established here. Instead, we begin by observing, lest it be forgotten, that Miliband's later writings were not predominantly focused on the Labour Party, and from 1969 the focus of his work shifted to state theory. This shift - beginning with the publication of The State in Capitalist Society (1969) and his famous debate with the Greek socialist theorist Nicos Poulantzas - made him for a while one of the most internationally recognised intellectual figures in political science and sociology in the English-speaking world and beyond. In this change of focus and status, it was not that his original positions on the Labour Party were abandoned so much as generalised.

The thesis in The State was the by-now-standard one for the Milibandian 'school' as a whole. This was that democratic politics in advanced capitalist societies operate within powerful class constraints; and that these constraints are structured into the political domain through the conservatism of state bureaucracy, the force of business and financial interests, and the ideological pressure of capitalist values in the mass media. Social democratic parties of the Labour Party variety were not entirely ignored in this analysis; but they appeared there in less prominent roles. They appeared as orchestrators of capitalist legitimation and working-class demobilisation, as part of the political processes that accommodate democratic aspirations to capitalist power structures, and as 'singularly weak agencies of mass education in socialist principles and purposes' (Miliband 1969: 196). What in Parliamentary Socialism (1961) had been presented as a vulnerability to parliamentary socialisation now reappeared in The State in Capitalist Society as an 
inadequate capacity for counter-hegemonic politics. Hence the latter book singled out Labour leaders' 'ideological defenses' as being 'generally not . . . of nearly sufficient strength to enable them to resist with any great measure of success conservative pressure, intimidation and enticement' (Miliband 1969: 195).

What was presented in general terms in The State also reappeared as very much a United Kingdom phenomenon, in Miliband's Capitalist Democracy in Britain (1982). There, the compatibility of capitalism with democracy, now explained in neo-Gramscian terms, was seen as a consequence of 'the hegemony exercised by the dominant class and its conservative forces' (1982: 15). The capacity of that hegemony to survive unscathed was, in considerable measure, still seen as a product of past Labour Party policy. Miliband was clear on this when critiquing the arguments of his mentor Harold Laski:

The whole political scene would indeed have been transformed had the Labour Party in the inter-war years been the socialist party which he wanted it to be, or at least believed that it must soon become. But one of the most significant facts about the British political scene was precisely that the Labour Party was not then, and was not on the way to becoming, such a party. This gave Laski's argument a certain air of unreality, which the passage of time has made even more pronounced. This is a great pity because the argument itself is right: the political system would be fundamentally affected if the Labour Party (or any other party) did become a major force for socialist change; even more so if it was able to form a government and sought to implement a programme of socialist policies. But the fact is that the political system has never had to face such a situation. This of course is something which itself requires explanation. (Miliband 1982: 16)

Key to that explanation for Miliband, in 1982 as much as in 1961, was the Labour Party's own exposure to (and enthusiasm for) the rules and institutions of parliamentarism as these were generally understood among the British political class. 'Nothing', he wrote,

has weighed more heavily upon labour politics in Britain than the existence of a strong framework of representation: however inadequate and undemocratic it might be, there did exist, it was believed, a solid proven structure that could be made more adequate and democratic, that had already undergone reform, and that in due course could be used to serve whatever purpose a majority might desire, including the creation of a socialist order. (Miliband 1982: 27)

Parliamentarism of this kind worked, according to Miliband, by co-option and incorporation. 'It simultaneously [enshrined] the principle of popular inclusion and that of popular exclusion' (Miliband 1982: 38): co-opting and incorporating the working class as an electorate, their more radical parliamentary representatives, and their trade union leaderships. The British parliamentary State sustained the private rule of capital in the UK by drawing all these potentially oppositional social forces and political institutions into a form of democratic politics that left elected governments subject to the constraints of a conservative state apparatus and a well-entrenched business and financial class, and left their electorate subject to heavy ideological pressure from schools, churches and the media. The Labour 
Party leadership, Miliband argued, had long been an active player in that process of political socialisation and incorporation: training early generations in the rules of parliamentary politics (especially in the illegitimacy of the use by Labour of industrial power for political ends); and repressing (until challenged by the Bennite internal party reforms of the early 1980s) internal party democracy, so that MPs could remain free of effective pressure from constituency activists and Labour Cabinets could remain free of party control (Miliband 1982: 68-76).

\title{
The question of 'betrayal'
}

Quite contrary to what their less than careful critics often assert, neither Miliband nor Saville subscribed to some 'sell-out' theory of British labour, some notion that the British working class was inherently socialist but was persistently betrayed by its moderate political leadership. The Milibandian understanding of the relationship between Labour as a political party, the working class as a social force and socialism as a body of ideas was always far more complex than that. As Marxists Miliband and Saville always believed that the contradictory relationship between capital and labour in a capitalist society precludes an effective long-term realisation of working-class interests without a major resetting of property relationships. They did not apologise for perpetually raising the socialist question, seeing it still a legitimate issue to discuss when exploring left-wing political formations. But their critique of British Labour was not that an already existing socialist working class required better political leadership. Such a claim constituted, in Miliband's view, a 'gross overestimation of the strength of the socialist forces in the Labour Party and in the labour movement at large' and, as such, 'obvious nonsense' (Miliband 1977a: 47). He later wrote:

\begin{abstract}
There is no point pretending that there exists a ready-made majority in the country for a socialist programme. How could there be? One of the fruits of the long predominance of labourism is precisely that the party of the working class has never carried out any sustained campaign of education and propaganda on behalf of a socialist programme; and that Labour leaders have frequently turned themselves into fierce propagandists against the socialist proposal of their critics inside the Labour Party and out, and have bent their best efforts to the task of defeating all attempts to have the Labour Party adopt such proposals. Moreover, a vast array of conservative forces, of the most diverse kind, are always at hand to dissuade the working class from even thinking about ... socialist ideas ... a ceaseless battle for the 'hearts and minds' of the people is waged by the forces of conservatism, against which have only been mobilized immeasurably smaller socialist forces. (Miliband 1983a: 304-5)
\end{abstract}

The Milibandian thesis was never that an inherently socialist working class was periodically betrayed by Labour Party moderation. It was rather that the possibility of creating such a radicalised class has been blocked by, among other things, the presence of a party committed to Labourism rather than socialism, and the periodic leftwards shift in rhetoric made by the Labour Party whenever working-class militancy intensified. The Milibandian argument was always that the emergence of such a working class was, with the Labour Party in the way, extraordinarily 
difficult to trigger; but it was also that the creation of mass support for socialist programmes was both possible and necessary. The whole thrust of the Milibandian argument on the working class and socialism was that the fusion between the two was one that had to be created, and that such a creation required clear and unambiguous political leadership of a kind that the Labour Party systematically declined to offer. As Miliband and Marcel Liebman (1986: 481) put it:

The notion that very large parts of 'the electorate', and notably the working class, is bound to reject radical programmes is a convenient alibi, but little else. The real point, which is crucial, is that such programmes and policies need to be defended and propagated with the utmost determination and vigour by leaders totally convinced of the justice of their cause. It is this which is always lacking: infirmity of purpose and the fear of radical measures lies not with the working class but with the social democratic leaders themselves.

Careless critics have therefore moved too quickly to condemn those who take this perspective for misunderstanding the Labour Party's project as something other (and more radical) than it was. Not so. They always understood that project - in all its moderation and episodic radicalism - well enough. They simply found it wanting both when measured against its own promises and when set on the wider map of European and global working-class politics.

\section{The Miliband legacy}

To dwell, as we have thus far, on Ralph Miliband's contribution to the study of the Labour Party minimises the great effect of the broader role he played in founding a creative new current of Marxist political analysis. The remit of his Marxism and Politics (1977b: 14), arguably his greatest book, was the need to show clearly

what a Marxist political theory specifically involves; and to indicate how far it may serve to illuminate any particular aspect of historical or contemporary reality. For this pupose, the developments in Marxist political thinking in recent years have obviously been of great value, not least because the constricting 'triumphalism' of an earlier period has been strongly challenged and the challenge has produced a much greater awareness among Marxists that Marxism, in this as much as in other realms, is full of questions to be asked and - no less important - of answers to be questioned. Many hitherto neglected or underestimated problems have attracted greater attention; and many old problems have been perceived in better light. As a result, the beginnings have been made of a political theorization in the Marxist mode. But these are only beginning.

It was this broader perspective, this invitation to go beyond the old Marxist paradigm and create a new and richer one, that excited the new generation of intellectuals and scholars that emerged in the 1960s and 1970s, the two of us among them. Unconnected with each other in any way, we took up many of the themes that Miliband (and Saville) had already sounded in their studies of Labourism, seeking not only to extend their account of the contemporary party's history but also to develop further the conceptual apparatus for doing so. Like Miliband, we also 
sought to go beyond the Labour Party in this respect and to contribute to the development of Marxist political theory in general. Unlike him, however (he once privately admitted to being bored by economics), we also sought to engage on this basis with the new Marxist political economy. Thus in our accounts of the Labour Party from the 1960s to the 1990s we both built on what he had established and yet departed from him in various ways. This meant telling the history of policy and intra-party conflict in more detail than he did, and concentrating much more on economic policy and political economy.

Miliband was therefore not alone in turning from the focused analysis of one political party to a more general political sociology of social democracy and the State. By the mid-1970s Leo Panitch had already intervened significantly in the emerging international debate on corporatism (Panitch 1977a, 1980a, 1981), and had made his initial contributions to the new Marxist work on the State (Panitch 1976, 1980b, 1986b, 1986c). After Labour in Power? (Coates 1980), Coates's own Gramscian turn then produced The Context of British Politics (1984a) and Running the Country (1995 [1990]), both of which sit alongside Colin Leys's Politics in Britain (1983) as major attempts to produce a general assessment of the parameters of Labour politics in the manner of Miliband's writings on the State. Such initiatives then extended into intellectual territory that Miliband did not explore rounding out this Marxist political sociology with a series of studies in international and comparative political economy. Panitch encouraged (and developed himself) a new approach to democratic state administration (Albo, Langille and Panich 1993) and a distinctive Socialist Register position on the relationship of globalisation to the State (Panitch 1994); and Coates produced, first, a detailed survey of British economic under-performance (Coates 1994) and then a comparative study of models of capitalism (1999a, 2000a). This set of later publications produced new frameworks for analysing developments in Labour politics: not only by exploring the limits of Old Labour politics through a discussion of 'corporatism', but by examining the limits of New Labour through notions of 'progressive competitiveness'. In this way, a Milibandian perspective was eventually brought to the analysis of New Labour, one that was armed with a range of concepts and arguments that went beyond those available to it in the first phase of its work on the Labour Party.

\section{The issue of 'corporatism'}

The first moves in these new directions came in response to the experience of Labour in power between 1974 and 1979. Through his intervention in the famous profits squeeze debate of the 1970s, Panitch stressed the centrality of class conflict to understanding the crisis of the British economy (Panitch 1977b). In a study initially designed as an update of The Labour Party and the Struggle for Socialism, Coates developed what was an early attempt at Milibandian political economy to explain Labour's dismal performance in office. In Labour in Power? (1980) Coates argued that, though vital as a first step, it was no longer enough merely to list the range of powerful interests constraining Labour governments, because to do only 
that was to imply that those interests were in control of their world even if Labour was not in control of its. What was needed instead was the recognition that 'neither private elites nor public figures either understood or were in complete control of the main processes which shaped the world economy over which they presided, and that it was the capitalist nature of that world economy that ultimately held the key to the failure of this Labour Government and to the growing estrangement of trade unionists from it. 'To understand the events of the 1970s', Coates (1980: 160-1) argued, 'to assess the true impact of elite constraints, to place the power of British trade unionism, and to discuss the future of the Left in Britain, the question of capitalism had to be faced, and its impact on British politics fully understood.'

The question was how best to do that. One answer came from a systematic examination of the class constraints then eroding the viability of corporatism. In a widely cited article written against the background of the second Wilson Government, Panitch (1977a: 66) defined corporatism as 'a political structure within advanced capitalism which integrates organized socio-economic producer groups through a system of representation and co-operative mutual interaction at the leadership level and of mobilization and social control at the mass level', emphasising its inherent instability with the presence of strong social democratic labour movements. The class parameters surrounding even the corporatist version of the capitalist state, Panitch argued, and the resulting policy outputs reflecting 'capitalist class dominance' had eventually to draw the unions out of corporatist structures, or had at least to oblige them 'to abstain from accommodative behaviour if they were not to be repudiated by their rank and file membership' (Panitch 1977a: 138). This explanation of the propensity of Labour governments to succumb to winters of discontent of the 1978-79 variety also figured in David Coates's later writings on this last example of Old Labour in power. What Labour then understood to be socialism, he wrote,

was more properly understood as a mild form of corporatism, the sharing of political power with bureaucratized trade union leadership and corporate capital. Yet ... this power sharing was itself a major barrier to capital accumulation, and so proved destructive of the very economic growth that Labour governments sought to extract from the mixed economy ... For even on such favourable political and industrial terrain corporatism proved to be extraordinarily brittle. Anaesthetizing rather than removing the basic cleavage of interest between capital and labour, by pushing that tension down to lower levels of decision-making, corporatist structures . . . in the end fell victim to the contradictions they were supposed to suppress. (Coates 1984a: 258; see also Coates 1984b: 131)

\section{The political economy of 'New Labour'}

This repositioning of the study of the Labour Party on the wider canvas of state theory and corporatist political practice moved the centre of gravity of such studies away from the detail of Labour Party political developments into a more general analysis of capitalism and the contemporary state. That move was accentuated 
through the course of the 1980s and 1990s by further emphasis on questions of political economy. The long years of Thatcherism imposed their own imperative here. David Coates probed the adequacy of Thatcherite claims about the adverse economic consequences of a strong labour movement, and argued against the lowwage, low-welfare, growth strategy that the Conservatives were then pursuing. Panitch followed his colleague Greg Albo in theorising that strategy as one of 'competitive austerity', contrasted it to the emerging Centre-Left enthusiasm for strategies of 'progressive competitiveness', and developed arguments about the inadequacies of each (Albo 1994, 1997). As New Labour repositioned the party's economic policies - from both the radical statism of both the Bennite alternative economic strategy and Old Labour corporatism - Panitch saw parallels between Labour's growing enthusiasm for reskilling as the key to industrial modernisation and 'Clintonomics', and warned the Left about both.

The two centuries-old search for a cross-class 'producer' alliance between labour and national capital as an alternative to class struggle has taken shape in recent years in the form of the progressive competitiveness strategy, but its weaknesses have been very quickly revealed in the context of the globalization of capital. (Panitch 1994: 87)

Similar arguments were by then appearing sequentially in Coates's writings on the British economy. These came first in the form of a critique of Thatcherite low wage-growth strategies (Coates 1994), and later as critiques of New Labour's emerging political economy and of contemporary social democratic growth strategies of the Swedish or Clinton-Reich variety (Coates 1999a, 1999b, 2000a). By the time Models of Capitalism was published, towards the end of New Labour's first term, those following a Milibandian perspective had equipped themselves with a set of political economy theses that both illuminated central weaknesses in New Labour's economic strategy and rounded out what had hitherto been an approach to the politics of Labour more narrowly anchored on the terrain of history and sociology.

\section{Limits to Labour Party radicalism}

Between the 1980s' writings on the limits of Old Labour's corporatism and the 1990s' writings on the dangers of New Labour's enthusiasm for 'progressive competitiveness' - came a further refining and deepening of some of the older strands of the Milibandian approach to Labour politics. This focused particularly on the inability of the party to transform itself into an effective counter-hegemonic force, and the inability of the Labour Left, however well endowed, to transform Labour into a socialist organisation. The argument on the link between Labour's electoral politics and its weakness as a hegemonic force occurs in a number of places in Coates's work (Coates 1983: 98; 1986: 423; 1989: 102-3; 1996a: 63-4). On each occasion Labour's electoral fragility was linked to its inability or refusal to forge more than an episodic and limited electoral relationship with its mass base. In 1996, Coates noted the high 'degree of assistance from external events and forces the Labour Party has always needed to create an electoral bloc sufficiently sub- 
stantial to give it parliamentary power', and its long-established failure to establish any of the institutions -'newspapers, clubs, communities' - of a fully functioning Labour movement. Restricting itself to a vote-getting relationship with its working-class base, so the argument went, and mobilising even that relationship only episodically, Labour left the formulation of mass opinion to more conservative sources of values and policy in the privately owned media. This left Labour marooned as a largely 'passive recipient of electoral swings', with its politics never normally in possession of 'sufficient magnetic force to redraw the shape of electoral Britain by the power of its own programme and possibilities alone'. No wonder, then, Coates (1996a: 63-4) argued, that majorities so gratuitously won were easily lost, or that 'Labour majorities when they come tend to be accidental rather than created, and invariably prove to be as tenuous as they are fortuitous'.

Although most of those inspired by Miliband moved away from Labour Party studies to produce more general work that engaged with political sociology and political economy, those adopting a Milibandian view were not silent on the detail of developments within the party during its long years of opposition after 1979. In fact, they played a full part in the debates triggered by the 1983 electoral defeat. They argued in particular against the 'move to the right' logic of Eric Hobsbawm's The Forward March of Labour Halted? (Mulhern and Jacques 1981; see Coates 1983; Panitch 1986a) while also chronicling and commenting on the party's policy trajectory after 1983 (Coates 1996a). Panitch and Leys's The End of Parliamentary Socialism (2001 [1997]), dedicated as it was to Miliband's memory, directly spoke to the continuing relevance and importance of the approach he pioneered to the understanding of the detailed internal development of the Labour Party. Ever since Parliamentary Socialism, the argument for socialist politics had engaged with successive generations of the Labour Left; but not until The End of Parliamentary Socialism had any of the academics closely associated with Miliband addressed themselves in a detailed, focused and sympathetic way to Left Labour politics. That omission was now addressed, with the post-1970 Labour Left treated as a new Left sensitive to the weaknesses of its predecessors. The End of Parliamentary Socialism offered a detailed guide to the conflict within the party from 1970 to 1983. It explored the radical democratic character, as well as the weaknesses, of Bennism, the Campaign for Labour Party Democracy and the alternative economic strategy. It documented the role the union leadership and the Old Left played in their ultimate defeat; and then analysed the process of policy reformulation and the disempowerment of activism within the Labour Party up to the end of the century.

The end result of this intellectual journey has been the creation of a distinctively Milibandian voice in the current set of debates on the nature and potential of New Labour. The Milibandian voice in the burgeoning literature triggered by the 1997 victory has been distinctive in at least three ways. Though as concerned as other scholars and commentators to isolate what is new is New Labour's 'Third Way' (Panitch and Leys 2001: 237-61; see Coates 2000b), it has been distinctive partly through its propensity to combine its recognition of novelty with an emphasis on continuities in the politics of New Labour: underlying continuities (with Old Labour) in the party's continuing enthusiasm for a co-operative relationship with 
the business community; continuities with Gaitskellite revisionism from the 1950s; and continuities (between New Labour and the Major Government which preceded it) in basic industrial and employment policy (Coates 2000c). In this writing on New Labour, therefore, there is still more than an echo of Miliband's propensity to see Labour leaderships of whatever stripe as a political force which acts 'as a safe alternative government for the British establishment' (Panitch and Leys 1997: 218).

The school's scholarship remains distinctive, too, in the persistence of its focus on New Labour's economic and social policy. Unlike many other analyses of New Labour, it has not set much store by the Blairites' constitutional agenda, preferring instead to address the policy (and ultimately electoral) consequences of New Labour's enthusiasm for the 'new growth theory. This focus definitely reflects the school's post-1980 shift away from Labour Party studies mentioned earlier, a shift that ironically and by a quite circuitous route left those influenced by Miliband well positioned to explain the constraints on New Labour when the revamped Labour Party returned to power. For by moving the focus of our work into international and comparative political economy, those of us who earlier had been so persuaded by Miliband's work on the Labour Party found that, when we came back to writing about New Labour, we were better situated to write about the Blairite economic project than were many of the scholars whose work had remained sharply focused on party politics and party issues alone, as ours, broadly speaking, had not.

A third distinctive feature of our work on New Labour in power has been its propensity still to measure New Labour's performance - as once we measured Old Labour's - against various kinds of socialist yardsticks. By those tests, the party led by Tony Blair is far less a party of social reform even than was that led by Harold Wilson; and of course the Blair-led Government is light years away from the reformist party long sought by the Labour Left - the one briefly brought into view again by Bennite pressure between 1970 and 1983 before being 'modernined' away by Kinnock and Blair. As Colin Leys (who joined Panitch as co-editor of The Socialist Register in 1997) argued well before New Labour came to power, to criticise such policy realignments was not to deny that policy modernisation was necessary to win victory after nearly two decades in opposition. What did concern him, however, even before they came to office, was whether, as New Labour deployed 'the buzzword of "modernization" to good short-term electoral effect ... any serious project for social change, let alone one that can seriously be called socialist, can be constructed on such a foundation' (Leys 1996: 26). In keeping with the Milibandian perspective as a whole, he proved correct in thinking that the answer to that concern would soon be given with a resounding 'No'.

The development of such arguments since 1979 means that additions now need to be made to the three core elements of the Milibandian perspective on the Labour Party laid out at the start of this chapter. To those can be added, fourth, the centrality of corporatism to the politics of Old Labour, and the particular inappropriateness of that form of politics to parties of social reform in an economy with so weak a manufacturing base and so globally focused a set of financial insti- 
tutions. Fifth, the peculiarly electoralist nature of the Labour Party's relationship with its potential mass base, and the particularly inappropriate nature of that relationship for a party requiring to consolidate a counter-hegemonic presence. Sixth the attractiveness of the Bennite attempt to reset Labour Party politics, and the necessary limits of that attempt. Seventh, there should be added the centrality to the New Labour project of strategies of 'progressive competitiveness', and the particular inappropriateness of those strategies for a party seeking both a prolonged period of majority electoral support and a strengthened industrial base from which to finance social provision.

\section{The continuing relevance of the Milibandian perspective}

Complex and extensive bodies of argument require careful reading, and such readings take time - time that many critics of the Milibandian perspective have not always afforded it. As we noted at the start of this chapter, too often the whole corpus has been dismissed as merely criticising the Labour Party for not being a socialist party when in truth it had never set out to be one; as though that was the argument being offered in Parliamentary Socialism and in the scholarship inspired by it. But that was never the Milbandian view of the Labour Party. The Labour Party has always been understood from within this perspective - even at moments of the party's greatest radicalism - as at most a reformist party. It has always been understood, moreover, as more normally at best a party of social reform, one within which Centre-Left and Centre-Right social democrats battled for dominance (with the latter invariably in the ascendant). The whole focus has been not on the politics of Labour as a party that betrays its own socialist goals and its already socialist working-class constituency, but on the politics of labourism and its consequences. The whole focus has been on a party that was moderate in its fundamental aims, even when these were articulated in some form of socialist discourse. Such scholarship has always understood the Labour Party as one which, through its particularly 'narrow interpretation of parliamentary democracy' (Panitch 1988: 349), locked itself very early in its career onto a trajectory of increasing conservatism, a trajectory which arguably has now repositioned the party to the Right of any programmatic position that could be described as even progressive, let alone socialist, in intent. The Milibandian perspective has always conceded the presence within the Labour Party of individuals and programmes of a socialist or progressive kind; but it has always insisted too that socialists within the party have never enjoyed more than a minority and subordinate presence.

The frustration which more moderate commentators on Labour matters down the years have expressed with Milibandian writings seems to have been created in part by the fact that the concept of 'socialism', used as a yardstick against which to judge New, as well as Old, Labour appears insufficiently defined. In defence we would simply say that this frustration ignores those writings in the Milibandian genre that do offer varying degrees of specification of what may be meant by 'socialism' today. There have been many such (Albo 1994; Albo, Langille and Panitch 1993; Burden, Breitenbach and Coates 1990; Leys 1999; Miliband 1977, 1994b; 
Panitch 1980b, 2001; Panitch and Gindin 1999; Wainwright 1994). It is not that there is a single Miliband-inspired definition of an alternative order. Such a specification would have an arbitrariness that would render it valueless. It is rather that we can point to various moves to specify part of what that socialism might be, to put some flesh on what Panitch and Leys's 2000 Socialist Register termed 'necessary utopias', to engage in what Gindin and Panitch in that volume called 'rekindling the socialist imagination'. If Labour Party scholars do not read this work, it says something significant - and sad - about their lack of interest in answering the question: what is socialism? In that sense, the frustration of those who criticise Milibandians for their lack of clarity is matched by our frustration with their apparent total lack of interest in the issue of alternatives to the status quo.

The Milibandian argument has always been, in that sense, an argument addressed only to part of the audience interested in the Labour Party. It has been (and it remains) an argument - a set of theses about Labour and its possibilities addressed primarily to the concerns of socialists - those inside the Labour Party itself and those beyond. Is activity within the party a precursor of the creation of a mass base for socialist politics, or a debilitating distraction from that creation? This is the central Miliband question. Those who take that perspective have always been keen to ally with the Labour Left and to support its growth (Panitch and Leys 1997: 268). Ultimately, however, they have also been, as Hilary Wainwright once called herself, 'obstinate refusniks' (Wainwright 1987: 6) on the question of taking membership of the Labour Party for socialist purposes. And they have always recognised that the creation of a socialist working class in Britain was a task that would take a long time, which is one reason why they have argued that the Labour Party's short-term electoral concerns so obviously predisposed the party against any attempt to undertake it.

A final word on the importance of Ralph Miliband himself. Because time is passing since his death, and because his major writings of the late 1960s were not directly focused on the Labour Party, there is a danger that new generations of Labour Party scholars will discount his importance. That would be a great loss to left-wing scholarship in Britain. We have separately recorded our own personal debts to him and his work (Coates 1996b; Panitch 1995); but the debt (and the importance of his work) runs wider than that. Ralph Miliband was a member of that generation of socialist intellectual giants who, by the sheer force of their personalities, the charisma of their teaching and the quality of their scholarship created a huge (and more or less safe) intellectual space within which radical students could pursue radical research. Before them, the range of the tolerable (and the tolerated) in the study of British Labour was narrow and arcane. We have the freedom to react to them now, to decide how much to take from their work as our own, because they won for us a width and a quality of scholarship missing in their youth. This intellectual space has been much eroded of late by the enthusiastic absorption of neo-liberal orthodoxies by the vast majority of Centre-Left parties; which is one of the reasons why we believe that intellectuals of their stature are needed again: to stem and to reverse that tide. 


\section{References}

Unless indicated, the place of publication is London.

Albo, G. (1994) 'Competitive austerity and the impasse of capitalist employment policy', in Miliband, R. and Panitch, L. (eds) The Socialist Register 1994

Albo, G. (1997) 'A world market of opportunities? Capitalist obstacles and Left economic policy', in Panitch, L. (ed.) The Socialist Register 1997

Albo, G. Langille, D and Panitch, L. (eds) (1993) A Different Kind of State: Popular Power and Democratic Administration, Toronto

Brivati, B. and Heffernan, R. (eds) (2000) The Labour Party: A Centenary History

Burden, T., Breitenbach, H. and Coates, D. (1990) Features of a Viable Socialism

Coates, D. (1975) The Labour Party and the Struggle for Socialism, Cambridge

Coates, D. (1980) Labour in Power? A Study of the Labour Government 1974-79

Coates, D. (1981) 'The Labour Left and the transition to socialism', New Left Review, 129

Coates, D. (1982) 'The limits of the Labour Left: space and agency in the transition to socialism', New Left Review, 135

Coates, D. (1983) 'The Labour Party and the future of the Left', in Miliband, R. and Saville, J. (eds) The Socialist Register 1983

Coates, D. (1984a) The Context of British Politics

Coates, D. (1984b) 'Corporatism and the State in theory and practice', in Harrison, M. (ed.) Corporatism and the Welfare State, Aldershot

Coates, D. (1986) 'Social democracy and the logic of political traditions', Economy and Society, $15: 3$

Coates, D. (1989) The Crisis of Labour, Oxford

Coates, D. (1994) The Question of UK Decline

Coates, D. (1995 [1990]) Running the Country

Coates, D. (1996a) 'Labour governments: old constraints and new parameters', New Left Review, 219

Coates, D. (1996b) 'The view at half-time: politics and UK economic under-performance', University of Leeds Review, 38

Coates, D. (1996c) 'Roger Scruton and the New Left', in Kirk, N. (ed.) Social Class and Marxism, Aldershot

Coates, D. (1999a) 'Models of capitalism in the new world order: the British case', Political Studies, $47: 4$

Coates, D. (1999b) 'Labour power and international competitiveness: a critique of ruling orthodoxies', in Panitch, L. and Leys, C. (eds) The Socialist Register 1999

Coates, D. (1999c) 'Placing New Labour', in Jones, B. (ed.) Political Issues in Britain Today, 5th edition, Manchester

Coates, D. (1999d) “The novelty of New Labour: the view at half-time', paper to the American Political Science Association's Annual Conference, Atlanta, GA

Coates, D. (2000a) Models of Capitalism: Growth and Stagnation in the Contemporary Era, Cambridge

Coates, D. (2000b) 'The character of New Labour', in Coates, D. and Lawler, P. (eds) New Labour in Power, Manchester

Coates, D. (2000c) 'New Labour's industrial and employment policy', in Coates, D. and Lawler, P. (eds) New Labour in Power, Manchester

Hobsbawm, E. (1978) 'The forward march of Labour halted?', reprinted in Mulhern, F. and Jacques, M. (eds) (1981) The Forward March of Labour Halted? and Hobsbawm, E. (1989) Politics for a Rational Left 
Jefferys, K. (2000) 'The Attlee years', in Brivati, B. and Heffernan, R. (eds) The Labour Party: A Centenary History

Leys, C. (1983) Politics in Britain, Toronto

Leys, C. (1996) 'The British Labour Party's transition from socialism to capitalism', in Panitch, L. (ed.) The Socialist Register 1996

Leys, C. (1999) 'The public sphere and the media', in Panitch, L. and Leys, C. (eds) The Socialist Register 1999

Miliband, R. (1961) Parliamentary Socialism

Miliband, R. (1965) 'What does the Left want?', in Miliband, R. and Saville, J. (eds) The Socialist Register 1965

Miliband, R. (1969) The State in Capitalist Society

Miliband, R. (1972) Parliamentary Socialism, 2nd edition

Miliband, R. (1976) 'Moving on', in Miliband, R. and Saville, J. (eds) The Socialist Register 1976

Miliband, R. (1977a) 'The future of socialism in England', in Miliband, R. and Saville, J. (eds)

The Socialist Register 1977

Miliband, R. (1977b) Marxism and Politics, Oxford

Miliband, R. (1978) 'A state of de-subordination', British Journal of Sociology, 29:4

Miliband, R. (1982) Capitalist Democracy in Britain, Oxford

Miliband, R. (1983a) Class Power and State Power

Miliband, R. (1983b) 'Socialist advance in Britain', in Miliband, R. and Saville, J. (eds) The Socialist Register 1983

Miliband, R. (1989) Divided Societies: Class Struggle in Contemporary Capitalism, Oxford

Miliband, R. (1994a) 'Thirty years of “The Socialist Register", in Miliband, R. and Panitch, L. (eds) The Socialist Register 1994

Miliband, R. (1994b) Socialism for a Sceptical Age, Cambridge

Miliband, R. and Liebman, M. (1986) 'Beyond social democracy', in Miliband, R., Saville, J., Liebman, M. and Panitch, L. (eds) The Socialist Register 1985-86

Miliband, R. and Saville, J. (1964) 'Labour policy and the Labour Left', in Miliband, R. and Saville, J. (eds) The Socialist Register 1964

Panitch, L. (1971) 'Ideology and integration: the case of the British Labour Party', Political Studies, 19:2

Panitch, L. (1976) Social Democracy and Industrial Militancy: The Labour Party, the Trade Unions and Incomes Policy 1945-1974, Cambridge

Panitch, L. (1977a) 'The development of corporatism in liberal democracies', Comparative Political Studies, 10:1

Panitch, L. (1977b) 'Profits and politics: Labour and the crisis of British capitalism', Politics and Society, $7: 4$

Panitch, L. (ed.) (1977c) The Canadian State: Political Economy and Political Power, Toronto Panitch, L. (1979) 'Socialists and the Labour Party: a reappraisal', in Miliband, R. and Saville, J. (eds) The Socialist Register 1979

Panitch, L. (1980a) 'Recent theorizations of corporatism: reflections on a growth industry', British Journal of Sociology, 31:2

Panitch, L. (1980b) 'The State and the future of socialism', Capital and Class, 11

Panitch, L. (1981) 'The limits of corporatism: trade unions and the capitalist State', New Left Review, 125

Panitch, L. (1986a) 'The impasse of social democratic politics', in Miliband, R., Saville, J., Liebman, M. and Panitch, L. (eds) The Socialist Register 1985-86

Panitch, L. (1986b) Working Class Politics in Crisis: Essays on Labour and the State 
Panitch, L. (1986c) 'The tripartite experience', in Banting, K. (ed.) The State and Economic Interests, vol. 32, Toronto

Panitch, L. (1988) 'Socialist renewal and the Labour Party', in Miliband, R., Panitch, L. and Saville, J. (eds) The Socialist Register 1988

Panitch, L. (1994) 'Globalisation and the State', in Miliband, R. and Panitch, L. (eds) The Socialist Register 1994

Panitch, L. (1995) 'Ralph Miliband: socialist intellectual 1924-1994', in Panitch, L. (ed.) The Socialist Register 1995

Panitch, L. (2001) Renewing Socialism: Democracy, Strategy and Imagination, Boulder, CO, and Oxford

Panitch, L. and Gindin, S. (1999) 'Transcending pessimism: rekindling socialist imagination', in Panitch, L. and Leys, C. (eds) The Socialist Register 2000

Panitch, L. and Leys, C. (2001 [1997]) The End of Parliamentary Socialism: From New Left to New Labour

Panitch, L. and Leys, C. (eds) (2000) The Socialist Register 2000

Saville, J. (1967) 'Labourism and the Labour Government', in Miliband, R. and Saville, J. (eds) The Socialist Register 1967

Saville, J. (1970) 'Britain: prospect for the seventies', in Miliband, R. and Saville, R. (eds) The Socialist Register 1970

Saville, J. (1973) 'The ideology of Labourism', in Benewick, R., Berki, R. N. and Parekh, B. (eds) Knowledge and Belief in Politics

Saville, J. (1988) The Labour Movement in Britain

Saville, J. (1995) 'Parliamentary socialism revisited', in Panitch, L. (ed.) The Socialist Register 1995

Taylor, R. (2000) 'The trade unions and the formation of the Labour Party', in Brivati, B.and Heffernan, R. (eds) The Labour Party: A Centenary History

Wainwright, H. (1987) Labour: A Tale of Two Parties

Wainwright, H. (1994) Arguments for a New Left

Wainwright, H. (1995) 'Once more moving on: social movements, political representation and the Left', in Panitch, L. (ed.) The Socialist Register 1995 